HortSCIENCE 26(5):544-546. 1991.

\title{
Calcium Nutrition and Cultivar Influence Incidence of Tipburn of Collard
}

\author{
Jon R. Johnson ${ }^{1}$ \\ Clemson University Sandhill Research and Education Center Columbia, \\ SC 29224
}

Additional index words. Brassica oleracea, Acephala group, mineral nutrition

\begin{abstract}
The collard (Brassica oleracea, Acephala group) cultivar Vates was more susceptible than 'Blue Max' to tipburn in sand-culture and field studies. Calcium concentrations in young leaves were similar for both cultivars. 'Blue Max' appears to require a lower Ca concentration in young leaves than 'Vates' for normal growth. In sand-culture studies, increasing the Ca level in nutrient solution to $3 \mathrm{~mm}$ or higher decreased tipburn in 'Vates'. 'Blue Max' did not develop tipburn regardless of Ca level. Increasing the $\mathrm{Ca}$ level in nutrient solution increased $\mathrm{Ca}$ concentration in young and old leaves for both cultivars. Soil application of $\mathrm{CaSO}_{4}$ or foliar application of $\mathrm{Ca}\left(\mathrm{NO}_{3}\right)_{2}$ or $\mathrm{CaCl}_{2}$ did not decrease occurrence of tipburn in Yates', presumably because these treatments did not increase Ca concentrations in young leaves.
\end{abstract}

Tipburn of younger leaves of collard was observed during Summer 1988 in commercial fields in central South Carolina. The inward cupping and marginal bum of the young collard leaves appeared to be the same as those associated with tipburn of cabbage, cauliflower, and lettuce. Studies on cabbage (Maynard et al., 1965), cauliflower (Maynard et al., 1981), and lettuce (Collier and Tibbitts, 1984; Thibodeau and Minotti, 1969; Yanagi and Bullock, 1983) indicated that tipburn was caused by a localized $\mathrm{Ca}$ deficiency in the tip of the leaf. Soil application of $\mathrm{CaSO}_{4}$ or foliar application of $\mathrm{Ca}\left(\mathrm{NO}_{3}\right)_{2}$ or $\mathrm{CaCl}_{2}$ has been found to be effective in controlling tipburn of cauliflower (Gruesbeck and Zandstra, 1988).

Collard is a cool-season crop grown primarily in the spring and fall in the southeastern United States, but interest in growing collard during the summer is increasing due

Received for publication 17 Nov. 1989. Technical Contribution no. 3030 of the South Carolina Agricultural Experiment Station. The cost of publishing this paper was defrayed in part by the payment of page charges. Under postal regulations, this paper therefore must be hereby marked advertisement solely to indicate this fact.

'Assistant Professor. to the high gross return that can be obtained during this period. High temperature and humidity are common in the southeastern United States during the summer. High-temperature stress has been found to increase the incidence and degree of tipburn of lettuce (Yanagi and Bullock, 1983). High relative humidity has been determined to promote development of tipburn of cabbage (Palzkill et al., 1980). There is no information on the influence of $\mathrm{Ca}$ nutrition and cultivar on tipburn of collards grown under high temperatures. The objectives of these studies were to determine the influences of $\mathrm{Ca}$ nutrition and cultivar on the incidence of tipburn and leaf $\mathrm{Ca}$ concentrations of collards grown under high-temperature stress.

Sand-culture experiments. In two greenhouse experiments, collard plants were grown in quartz sand in 28-cm-diameter (15 liters) pots. The experimental design was a splitplot, with cultivars ('Vates' and 'Blue Max') as main plots and $\mathrm{Ca}$ treatments as subplots. Treatments were replicated five times. An experimental unit consisted of one plant in a pot. In Expt. 1, 4-week-old transplants in the three-leaf stage were planted on 10 Oct. 1988. Treatments were initiated on 12 Oct. 1988 and terminated with harvest on 17 Nov. 1988. All nutrient solutions contained $\left(\mathrm{mg} \cdot \mathrm{liter}^{-1}\right)$; 
Table 1. Severity of tipburn and Ca concentration in collard leaves as influenced by cultivar and Ca level in nutrient solution. (Sand culture, Expt. 1.)

\begin{tabular}{lcccc}
\hline \hline & $\begin{array}{c}\mathrm{Ca} \\
\text { level } \\
\text { Cultivar }\end{array}$ & $\begin{array}{c}\text { Tipburn } \\
\text { severity } \\
\text { (rating) }\end{array}$ & \multicolumn{2}{c}{$\begin{array}{c}\text { Ca concn in } \\
\text { leaves (\% dry wt) }\end{array}$} \\
\hline Vates & 1 & 3.8 & Young & Old \\
& 3 & 1.4 & 0.61 & 1.27 \\
& 5 & 1.0 & 1.53 & 3.09 \\
& 10 & 1.8 & 2.58 & 4.32 \\
Blue Max & & $\mathrm{L}^{* *} \mathrm{Q}^{* * \mathrm{w}}$ & 2.78 & $\mathrm{~L}^{* *} \mathrm{Q}^{* *}$ \\
& 1 & 1.0 & $\mathrm{~L}^{* *} \mathrm{Q}^{*}$ & 1.18 \\
& 3 & 1.0 & 0.60 & 2.95 \\
& 5 & 1.0 & 1.53 & 4.88 \\
& 10 & 1.0 & 2.15 & $\mathrm{~L}^{* *} \mathrm{Q}^{* *}$ \\
\hline \hline
\end{tabular}

${ }^{2}$ Cultivar $\times \mathrm{Ca}$ interaction significant for tipburn rating and nonsignificant for $\mathrm{Ca}$ concentration in young and old leaves.

${ }^{y}$ Visual tipburn rating on a scale of $1=$ no tipburn and $5=$ severe tipburn.

${ }^{x}$ Young leaves $=$ terminal five leaves, old leaves $=$ all leaves older than fifth leaf from terminal.

"Effects linear (L) or quadratic (Q) nonsignificant (NS) or significant at $P=0.05(*)$ or $0.01(* *)$.

Table 2. Plant dry weight and Ca concentration of collard leaves as influenced by Ca level in nutrient solution and by cultivar. (Sand culture, Expt. 2.) ${ }^{2}$

\begin{tabular}{|c|c|c|c|c|}
\hline \multirow[b]{2}{*}{ Cultivar } & \multirow{2}{*}{$\begin{array}{c}\text { Ca level } \\
(\mathrm{mM})\end{array}$} & \multirow{2}{*}{$\begin{array}{c}\text { Dry wt } \\
\text { (g/plant) }\end{array}$} & \multicolumn{2}{|c|}{$\begin{array}{c}\text { Ca concn in } \\
\text { leaves }\left(\% \text { dry wt) }{ }^{y}\right.\end{array}$} \\
\hline & & & Young & $\overline{\text { Old }}$ \\
\hline \multirow[t]{4}{*}{ Vates } & 1 & 30.77 & 0.51 & 1.33 \\
\hline & 5 & 34.88 & 1.55 & 4.00 \\
\hline & 10 & 35.98 & 2.04 & 5.28 \\
\hline & 1 then $10^{x}$ & 40.37 & 2.12 & 4.08 \\
\hline LSD $0.05^{w}$ & & NS & 0.50 & 0.45 \\
\hline \multirow[t]{4}{*}{ Blue Max } & 1 & 40.52 & 0.58 & 1.21 \\
\hline & 5 & 48.75 & 1.60 & 3.65 \\
\hline & 10 & 53.30 & 1.98 & 4.71 \\
\hline & 1 then $10^{x}$ & 46.34 & 2.21 & 3.62 \\
\hline LSD $0.05^{\mathrm{w}}$ & & 7.31 & 0.22 & 0.33 \\
\hline
\end{tabular}

${ }^{2}$ Cultivar $\times \mathrm{Ca}$ interaction nonsignificant for tipburn rating, plant dry weight, and Ca concentration in young and old leaves.

${ }^{y}$ Young leaves = terminal five leaves, old leaves = all leaves older than fifth leaf from terminal.

${ }^{x}$ One mm Ca for the first 3 weeks of the study and $10 \mathrm{~mm} \mathrm{Ca}$ thereafter through harvest.

"Mean separation between Ca treatment means within a cultivar by LSD at $P=0.05$. Nonsignificant

(NS) difference based on $\mathrm{F}$ test for difference between $\mathrm{Ca}$ treatments within a cultivar.

Table 3. Severity of tipburn and Ca concentration in collard leaves as influenced by Ca treatment and cultivar in the field. (Expt. 4.) ${ }^{2}$

\begin{tabular}{|c|c|c|c|}
\hline \multirow[b]{2}{*}{ Factor } & \multirow{2}{*}{$\begin{array}{l}\text { Tipburn } \\
\text { severity } \\
\text { (rating)y }\end{array}$} & \multicolumn{2}{|c|}{$\begin{array}{c}\text { Ca concn in } \\
\text { leaves }(\% \text { dry wt) }\end{array}$} \\
\hline & & Young & Old \\
\hline \multicolumn{4}{|l|}{ Cultivar } \\
\hline Vates & $3.0 \mathrm{a}$ & $0.72 \mathrm{a}$ & $1.59 \mathrm{a}$ \\
\hline Blue Max & $1.0 \mathrm{~b}$ & $0.56 \mathrm{~b}$ & $1.18 \mathrm{~b}$ \\
\hline \multicolumn{4}{|l|}{ Ca appliedw } \\
\hline None & $2.0 \mathrm{a}$ & $0.59 \mathrm{c}$ & $1.28 \mathrm{c}$ \\
\hline $\mathrm{CaSO}_{4}$, soil & $1.5 \mathrm{a}$ & $0.69 \mathrm{a}$ & $1.53 \mathrm{a}$ \\
\hline $\mathrm{Ca}\left(\mathrm{NO}_{3}\right)_{2}$, foliar & $2.0 \mathrm{a}$ & $0.62 b c$ & $1.40 \mathrm{~b}$ \\
\hline $\mathrm{CaCl}_{2}$, foliar & $2.0 \mathrm{a}$ & $0.65 \mathrm{ab}$ & $1.33 \mathrm{bc}$ \\
\hline
\end{tabular}

${ }^{2}$ Mean separation within columns, cultivars, and Ca treatments by LSD, $P=0.05$.

'Visual tipburn rating on a scale of $1=$ no tipburn and $5=$ severe tipburn.

${ }^{x}$ Young leaves $=$ terminal five leaves, old leaves $=$ eighth leaf from the terminal.

${ }^{\text {" }} \mathrm{CaSO}_{4}$ applied preplant broadcast at $200 \mathrm{~kg} \mathrm{Ca} / \mathrm{ha}$ and incorporated into the soil. $\mathrm{Ca}\left(\mathrm{NO}_{3}\right)_{2}$, and $\mathrm{CaCl}_{2}$ applied as weekly foliar sprays at $4 \mathrm{~kg} \mathrm{Ca} / \mathrm{ha}$ per application. Foliar Ca treatments were applied five times.

$234 \mathrm{~K}, 31 \mathrm{P}, 49 \mathrm{Mg}, 0.5 \mathrm{~B}, 0.5 \mathrm{Mn}, 0.05$ $\mathrm{Zn}, 0.02 \mathrm{Cu}, 0.01 \mathrm{Mo}$, and $1 \mathrm{Fe}$. Sequestrene 330 (iron chelate) was the source of Fe. Solutions (800 ml) containing 1, 3, 5, or $10 \mathrm{~mm} \mathrm{Ca}$, all with $15 \mathrm{~mm} \mathrm{NO}_{3}$, were added to the pots three times per week for the first 2 weeks after transplanting. On days between $\mathrm{Ca}$ applications, pots received 800 duration. Application of nutrient solution and deionized water was the same as in Expt. 1. An additional treatment was $1 \mathrm{~mm} \mathrm{Ca}$ for the initial 3 weeks of the study and $10 \mathrm{~mm}$ $\mathrm{Ca}$ thereafter. Five-week-old transplants in the four-leaf stage were planted 26 Jan. 1988. Treatments were initiated on 1 Feb. 1989 and terminated on 6 Mar. 1988. Daily maxima and minima in the greenhouse averaged $32 \mathrm{C}$ and $22 \mathrm{C}$, respectively.

Dry weights of young leaves (the terminal five leaves) and old leaves (all leaves older than the fifth leaf from the terminal bud) were recorded. At the completion of the studies, tipburn was rated, with $1=$ no tipburn and $5=$ severe tipburn. Tissue samples from the young and old leaves were dried at $70 \mathrm{C}$ and then ground to pass through a 20mesh screen. Leaf $\mathrm{Ca}$ concentrations were determined by atomic absorption spectroscopy.

Field experiments. Two field experiments were conducted with 'Vates' and 'Blue Max' collards grown on a Lakeland sandy soil (Thermic typic quartzipsamments) at Clemson Experiment Station, Columbia, S. C., during Summer 1989. The native soil Ca level before application of limestone was 340 $\mathrm{kg} \cdot \mathrm{ha}^{-1}$, which is considered to be in the low range. Dolomitic limestone was applied at $560 \mathrm{~kg} \cdot \mathrm{ha}^{-1} 6$ weeks before initiation of the studies. Preplant broadcast fertilizer $(10 \mathrm{~N}$ $4.4 \mathrm{P}-8.3 \mathrm{~K}$ ) that contained $1 \% \mathrm{Ca}$ was applied at $560 \mathrm{~kg} \cdot \mathrm{ha}^{-1}$. Plants were transplanted when they were in the three-leaf stage (4 weeks old). Plot size was $1.8 \mathrm{~m}$ wide $\mathrm{x}$ $12.2 \mathrm{~m}$ long. Each plot contained two rows of collards with $71 \mathrm{~cm}$ between rows and 46 $\mathrm{cm}$ between plants in the row. The experiment was a split-plot in a randomized complete block design, with cultivars as main plots and $\mathrm{Ca}$ fertilization method as subplots. Treatment combinations were replicated four times. A nonionic spray adjuvant (alkyl polyoxylkane ether) at $540 \mathrm{ml} \cdot \mathrm{ha}^{-1}$ was applied with all foliar $\mathrm{Ca}$ solutions. Foliar $\mathrm{Ca}$ solutions were applied with a tractor-mounted sprayer calibrated to apply 450 liters $\cdot$ ha $^{-1}$ at a pressure of $193 \mathrm{kPa}$. In Expt. 3, transplants were planted on 18 May 1989. Calcium treatments were: 1) control, 2) preplant broadcast soil application of $\mathrm{Ca}$ at $200 \mathrm{~kg} \cdot \mathrm{ha}^{-1}$ from $\mathrm{CaSO}_{4}$, 3) three weekly foliar applications each of $4 \mathrm{~kg} \mathrm{Ca} / \mathrm{ha}$ as $\mathrm{Ca}\left(\mathrm{NO}_{3}\right)_{2}$ starting 2 weeks after transplanting, and 4) one foliar application of $\mathrm{Ca}\left(\mathrm{NO}_{3}\right)_{2}$ as in treatment 3 applied 4 weeks after transplanting. Average air maxima and minima were $31 \mathrm{C}$ and 19C, respectively. Collards were provided with $25 \mathrm{~mm}$ of water per week from a combination of rainfall and irrigation to prevent moisture stress. Plants were harvested 37 days after transplanting.

General experimental procedure for Expt. 4 was the same as that described for Expt. 3. Transplants were planted on 28 June 1989. Calcium treatments for Expt. 4 included: 1) control, 2) preplant soil application of $\mathrm{Ca}$ at $200 \mathrm{~kg} \cdot \mathrm{ha}{ }^{-1}$ from $\mathrm{CaSO}_{4}, 3$ ) foliar applications of $4 \mathrm{~kg} \mathrm{Ca} / \mathrm{ha}$ per application as $\mathrm{Ca}\left(\mathrm{NO}_{3}\right)_{2}$, and 4 ) foliar applications of $4 \mathrm{~kg}$ $\mathrm{Ca} /$ ha per application as $\mathrm{CaCl}_{2}$. The foliar 
Ca treatments were applied five times on a weekly basis starting 10 days after transplanting. Average air maxima and minima were $32 \mathrm{C}$ and $21 \mathrm{C}$, respectively. Plants were harvested 42 days after transplanting.

Data collected at harvest included number of tipburned plants per hectare and $\mathrm{Ca}$ concentrations of whole-leaf tissue samples from young and old leaves. Young leaves consisted of the terminal five leaves. Old leaf samples were the eighth leaf from the terminal bud of the plant. Leaf samples were washed in deionized water before preparation for nutrient analysis. Tissue samples were analyzed using the same method as described for sand-culture studies.

Data analysis. Data from all studies were tested by analysis of variance to determine the significance of main effects of cultivar and $\mathrm{Ca}$ treatment and to determine the presence of interaction between these factors. Data from Expt. 1 were subjected to regression analysis, by cultivar, to determine the response to $\mathrm{Ca}$ level in the nutrient solution. Calcium treatment means within cultivar in Expt. 2 and means from Expts. 3 and 4 were separated by LSD test, $P=0.05$.

Sand culture. Increasing the Ca level from 1 to $10 \mathrm{~mm}$ increased $\mathrm{Ca}$ concentration in young and old leaves for both cultivars (Table 1). Increasing $\mathrm{Ca}$ concentration from 1 to $3 \mathrm{~mm}$ decreased incidence of tipburn for 'Vates', with further increases in $\mathrm{Ca}$ concentration having no effect (Table 1). Tipburn was absent on 'Blue Max' at any $\mathrm{Ca}$ concentration. Calcium concentration in young leaves was similar for both cultivars at each $\mathrm{Ca}$ treatment level. Calcium concentrations in older leaves were consistently higher for 'Vates' than for 'Blue Max'.

In Expt. 2, Ca concentration in young and old leaves increased as nutrient solution $\mathrm{Ca}$ level was increased from 1 to $10 \mathrm{~mm}$. However, plant dry weight of 'Vates' was not influenced by the $\mathrm{Ca}$ level in the nutrient solution, but that of 'Blue Max' plants supplied with $1 \mathrm{~mm} \mathrm{Ca}$ was lower than for those supplied with 5 or $10 \mathrm{~mm} \mathrm{Ca}$. Nutrient solution $\mathrm{Ca}$ level had no influence on incidence of tipburn for either cultivar (rating range, 1.0 to 2.8 for 'Vates', 1.0 for all 'Blue Max'). 'Vates' had a higher incidence of tipburn than 'Blue Max' (tipburn rating of 1.8 vs. 1.0, respectively) when averaged over the four $\mathrm{Ca}$ treatments (Table 2). Cultivars did not differ for $\mathrm{Ca}$ concentration in young leaves
('Vates'-1.55\% and 'Blue Max'-1.59\%, $P>\mathrm{F}=0.59$ ) when averaged over the four Ca treatments. 'Vates' had a slightly higher $\mathrm{Ca}$ concentration in the old leaves than did 'Blue Max' (3.67\% and 3.30\%, respectively, $P>\mathrm{F}=0.06$ ) when averaged over the four $\mathrm{Ca}$ treatments.

Calcium concentrations in young leaves of 'Vates' were similar for plants supplied with $10 \mathrm{~mm}$ for the entire study to those supplied with $1 \mathrm{~mm} \mathrm{Ca}$ at the beginning and $10 \mathrm{~mm}$ at the end (Table 2). For 'Blue Max', the Ca concentrations of young leaves were lower for plants supplied with $10 \mathrm{~mm} \mathrm{Ca}$ for the entire study than for those supplied with 1 $\mathrm{mm} \mathrm{Ca}$ at the beginning of the study and 10 $\mathrm{mm}$ at the end of the study. Calcium concentrations in old leaves were higher for plants of both cultivars supplied with $10 \mathrm{~mm} \mathrm{Ca}$ for the entire study than those supplied with 1 $\mathrm{mm} \mathrm{Ca}$ at the beginning and $10 \mathrm{~mm}$ at the end.

Field plantings. In Expt. 3, 49\% of the 'Vates' plants showed tipburn vs. $<1 \%$ for 'Blue Max' plants (significant difference at $P=0.01$ ). Calcium treatment had no influence on incidence of tipburn, possibly because of an adequate amount of $\mathrm{Ca}$ in the soil. Calcium concentrations of young and old leaves $(0.65 \%$ and $1.4 \%$, respectively) were not influenced by cultivar or Ca treatments. 'Vates' also was more susceptible to tipburn than 'Blue Max' in Expt. 4 (Table 3). Again, $\mathrm{Ca}$ treatments did not influence the severity of tipburn. Calcium concentrations in young and old leaves were higher for 'Vates' than for 'Blue Max'.

Soil and foliar $\mathrm{Ca}$ applications did not influence the severity of tipburn of collards in the field studies, most likely because a sufficient amount of $\mathrm{Ca}$ was supplied from the soil (native $\mathrm{Ca}$, dolomitic limestone, and preplant fertilizer). Adequate water (rainfall/ irrigation), provided to prevent moisture stress, may also have limited the response to $\mathrm{Ca}$ applications.

The critical leaf tissue $\mathrm{Ca}$ content for collard, used by most laboratories in the southeastern United States, is 3\% to $4 \%$ (most recently matured leaf). 'Vates' plants, grown in sand culture, produced the highest plant dry weight with $\mathrm{Ca}$ concentrations in young and old leaves of at least $0.51 \%$ and $1.33 \%$ (dry-weight basis), respectively (Table 2); for 'Blue Max', the analogous Ca concentrations were $1.60 \%$ and $3.65 \%$, respectively
(Table 2). Calcium concentration of the old leaves (most recently matured) was in the range of $1.28 \%$ to $1.53 \%$ for the field studies (Table 3). Optimal plant growth of collards, from these studies, was obtained with leaf $\mathrm{Ca}$ concentrations lower than the accepted critical leaf tissue $\mathrm{Ca}$ content.

Calcium concentrations in young leaves of 'Vates' were similar to or higher than for 'Blue Max'. Because tipburn of other Brassica spp., such as cabbage, is caused by a localized $\mathrm{Ca}$ deficiency in the tip of young leaves, it would be expected that $\mathrm{Ca}$ concentration would be lower for 'Vates' than 'Blue Max'. However, 'Vates' may require a higher $\mathrm{Ca}$ concentration than 'Blue Max' for normal growth, especially under hightemperature stress.

'Vates' was more susceptible to tipburn than 'Blue Max' in sand and field culture. Cultivars of cauliflower were found to differ in Ca efficiency (Hochmuth, 1984). Appropriate cultivar selection appears to be more effective than $\mathrm{Ca}$ applications in controlling tipbum of collards grown during the summer in the southeastern United States.

\section{Literature Cited}

Collier, G.F. and T.W. Tibbitts. 1984. Effects of relative humidity and root temperature on calcium concentration and tipburn development in lettuce. J. Amer. Soc. Hort. Sci. 109(2):128131.

Gruesbeck, R.V. and B.H. Zandstra. 1988. Calcium applications overcome tipburn in cauliflower. HortScience 23(3):827-828.

Hochmuth, G.J. 1984. Variation in calcium efficiency among strains of cauliflower. J. Amer. Soc. Hort. Sci. 109(5):667-672.

Maynard, D. N., B. Gersten, and H.F. Vernell. 1965. The distribution of calcium as related to internal tipburn, variety, and calcium nutrition in cabbage. Proc. Amer. Soc. Hort. Sci. 86:392396.

Maynard, D. N., D.C. Warner, and J.C. Howell. 1981. Cauliflower leaf tipburn: A calcium deficiency disorder. HortScience 16(2):193-195.

Palzkill, D. A., T.W. Tibbitts, and B.E. Struckmeyer. 1980. High relative humidity promotes tipburn on young cabbage plants. HortScience 15(5):659-660.

Thibodeau, P.O. and P.L. Minotti. 1969. The influence of calcium on the development of lettuce tipburn. J. Amer. Soc. Hort. Sci. 94(4):372376.

Yanagi, A.A. and R.M. Bullock. 1983. Factors involved in the development of tipburn in crisphead lettuce in Hawaii. J. Amer. Soc. Hort. Sci. 108(2):234-237. 